\title{
RELAP5/MOD3.3 Analysis of the Loss of External Power Event with Safety Injection Actuation
}

\author{
Andrej Prošek (iD and Marko Matkovič \\ Jožef Stefan Institute, Jamova cesta 39, SI-1000 Ljubljana, Slovenia \\ Correspondence should be addressed to Andrej Prošek; andrej.prosek@ijs.si
}

Received 30 December 2017; Accepted 13 February 2018; Published 23 April 2018

Academic Editor: Arkady Serikov

Copyright (C) 2018 Andrej Prošek and Marko Matkovič. This is an open access article distributed under the Creative Commons Attribution License, which permits unrestricted use, distribution, and reproduction in any medium, provided the original work is properly cited.

\begin{abstract}
The code assessment typically comprises basic tests cases, separate effects test, and integral effects tests. On the other hand, the thermal hydraulic system codes like RELAP5/MOD3.3 are primarily intended for simulation of transients and accidents in light water reactors. The plant measured data come mostly from startup tests and operational events. Also, for operational events the measured plant data may not be sufficient to explain all details of the event. The purpose of this study was therefore besides code assessment to demonstrate that simulations can be very beneficial for deep understanding of the plant response and further corrective measures. The abnormal event with reactor trip and safety injection signal actuation was simulated with the latest RELAP5/MOD3.3 Patch 05 best-estimate thermal hydraulic computer code. The measured and simulated data agree well considering the major plant system responses and operator actions. This suggests that the RELAP5 code simulation is good representative of the plant response and can complement not available information from plant measured data. In such a way, an event can be better understood.
\end{abstract}

\section{Introduction}

The integral effects facilities are scaled down and contain atypicalities; therefore plant measured data are very important for code assessment. The plant measured data come mostly from startup tests and operational events. Several such tests and events have been analyzed in the past [17]. Nevertheless, when an operational event occurred, not all plant data may be measured, which are important for interpretation of the events and physical understanding. Also, for some measured parameters part of history may be missing. In such a case well-simulated transient progression can help in reconstructing the plant response. The purpose of this study was twofold: on one hand to assess the latest version of RELAP5/MOD3.3 Patch 05 and on the other hand to better understand the plant response to the event with the reactor trip and safety injection signal actuation. The International Atomic Energy Agency (IAEA) specific safety guide number SSG-2 [8] (now in revision) states that "accident analyses may be used as a tool for obtaining a full understanding of events that occur during the operation of nuclear power plants and should form an integral part of the feedback from operating experience.” According to IAEA SSG-2 [8] the objective to analyze the operational events may be also to provide additional information on the time dependence of the values of parameters that are not directly available using the plant instrumentation, to check whether the plant operators and plant systems performed as intended and to validate and adjust the models in the computer codes that are used for analyses. In the present work, the RELAP5/MOD3.3 analysis of the abnormal event, which occurred on March 23, 2011, in Krško nuclear power plant (NPP), is presented. This event has been initially analyzed by earlier Patch 04 version of RELAP5/MOD3.3 computer code [9]. First the methods are described including abnormal event, standard RELAP5 input model of Krško NPP, and scenarios simulated. The RELAP5/MOD3.3 simulated results are then presented and compared to measured data that were available, followed by the discussion. At the end, the conclusions are given.

\section{Methodology Description}

First abnormal event is described for the selected plant. Then, the RELAP5/MOD3.3 Patch 05 [10] used for calculations and 
TABLE 1: Main sequence of events [11].

\begin{tabular}{lr}
\hline Event & Time (hh:mm:ss) \\
\hline Loss of offsite load & $10: 27$ \\
Turbine overspeed protection started (closure of turbine governor valves with steam dump valve opening) & $10: 27: 01^{*}$ \\
Alarm ROD BANK LO-LO LIMIT & $10: 28: 18$ \\
Safety injection signal & $10: 29: 02$ \\
"Unusual event" was declared & $10: 55$ \\
Diesel generator number 1 (2) stopped & $11: 20(11: 34)$ \\
Reactor coolant pump number 1 restarted & $11: 55$ \\
Plant transited to a "hot standby" mode, the termination of "unusual event" was declared & $12: 15$ \\
\hline
\end{tabular}

*Estimated from measured data; LO: low; LO-LO is also called LO-2.

the input model for selected pressurized water reactor (PWR) are described. Finally, the simulated scenarios are described.

2.1. Abnormal Event Description. Krško NPP is a two-loop PWR, Westinghouse type. Table 1 shows the main sequence of events. An abnormal event occurred on March 23, 2011, at 10:27. The initiating event was spurious activation of $400 \mathrm{kV}$ bus differential protection in the NPP's $400 \mathrm{kV}$ switchyard. Therefore the circuit breakers in the bays were disconnected, which caused loss of offsite load [11]. The turbine runback started to reduce the power. The turbine control system and steam dump system were not successful to stabilize the power and main steam line pressure. Approximately two minutes after the initiating event the low steam line pressure actuated the safety injection, which caused the reactor and turbine trip. The diesel generators automatically started on SI signal as designed (up to $10 \mathrm{~s}$ ) and safety systems started according to SI sequence (high pressure and low pressure safety injection pump with $5 \mathrm{~s}$ delay on SI signal and auxiliary feedwater pump with $20 \mathrm{~s}$ delay on SI signal). No measured start times were available, but it was reported that diesel generators and SI sequence performed as designed. Also, a loss of power supply occurred to safety buses and nonsafety buses because the generator load switch has been automatically disconnected. This resulted in the reactor coolant pumps stop. At 10:55, an "unusual event" was declared according to the emergency response procedure for loss of power to $6.3 \mathrm{kV}$ bus, which occurred at event occurrence. At the time of event declaration, the power has been supplied to safety buses through the auxiliary transformer. Later both diesel generators were manually shut down and placed in standby mode. When plant was safely shut down (bringing down to "hot standby" mode), the "unusual event" was ended.

The measured data received were recorded in the first four minutes of event. The measured parameters were available for primary and secondary side. The primary side parameters were nuclear power, rod position, pressurizer pressure, hot leg temperatures, cold leg temperatures, average reactor coolant system (RCS) temperatures, reference temperature, delta temperatures, overpower, and overtemperature delta temperature. The secondary side parameters were turbine firststage impulse pressure, steam generator pressures and water levels, steam and feedwater flows, turbine-generator rotor speed, and turbine governor valves position. The reported operator action was switching the feedwater flow control from automatic to manual mode with no further details. No information on steam demand, steam dump open logic signals, and steam dump flow was given.

2.2. RELAP5 Computer Code Description. The RELAP5/ MOD3.3 is best-estimate thermal hydraulic computer code delivered through Code Applications and Maintenance Program (CAMP) of U.S. Nuclear Regulatory Commission (NRC). It has been developed for best-estimate transient simulation of light water reactor coolant systems during postulated accidents such as loss of coolant, anticipated transients without scram (ATWS), and operational transients such as loss of feedwater, loss of offsite power, station blackout, and turbine trip. It can be used for simulating phenomena like core uncovery and core heatup up to the temperature of significant oxidation of the cladding and hydrogen production at around $1200^{\circ} \mathrm{C}$ to $1500^{\circ} \mathrm{C}$. For more information on the RELAP5/MOD3.3 Patch 05 code, the reader can refer to [10].

2.3. Krško Input Model for RELAP5. Krško NPP base RELAP5 input model has been used for simulations. This input model has been used first for reference calculations for Krško full scope simulator verification $[12,13]$. The analyses were performed for uprated conditions $(2000 \mathrm{MWt})$ with the new steam generators (SGs). The power uprate and steam generators replacement has been done in 2000. Later the RELAP5 input model has been validated by plant transients, for example, $[2,3]$. The input model represented by SNAP (see Figure 1) consists of 304 hydraulic components and 108 heat structures. For more details, the reader can refer to [9].

The primary side is modelled by the reactor pressure vessel (RPV) and two primary loops (loops 1 and 2) including reactor coolant pump (RCP) and U-tubes of steam generator. To the primary loop number 1 , the pressurizer (PRZ) vessel is connected through surge line (SL). At the top of pressurizer, the pressurizer spray lines, two pressurizer power operated relief valves (PORVs), and two pressurizer safety valves are connected. Active high pressure safety injection (HPSI) and low pressure safety injection (LPSI) pumps, and accumulators (ACCs) represent the emergency core cooling system. 


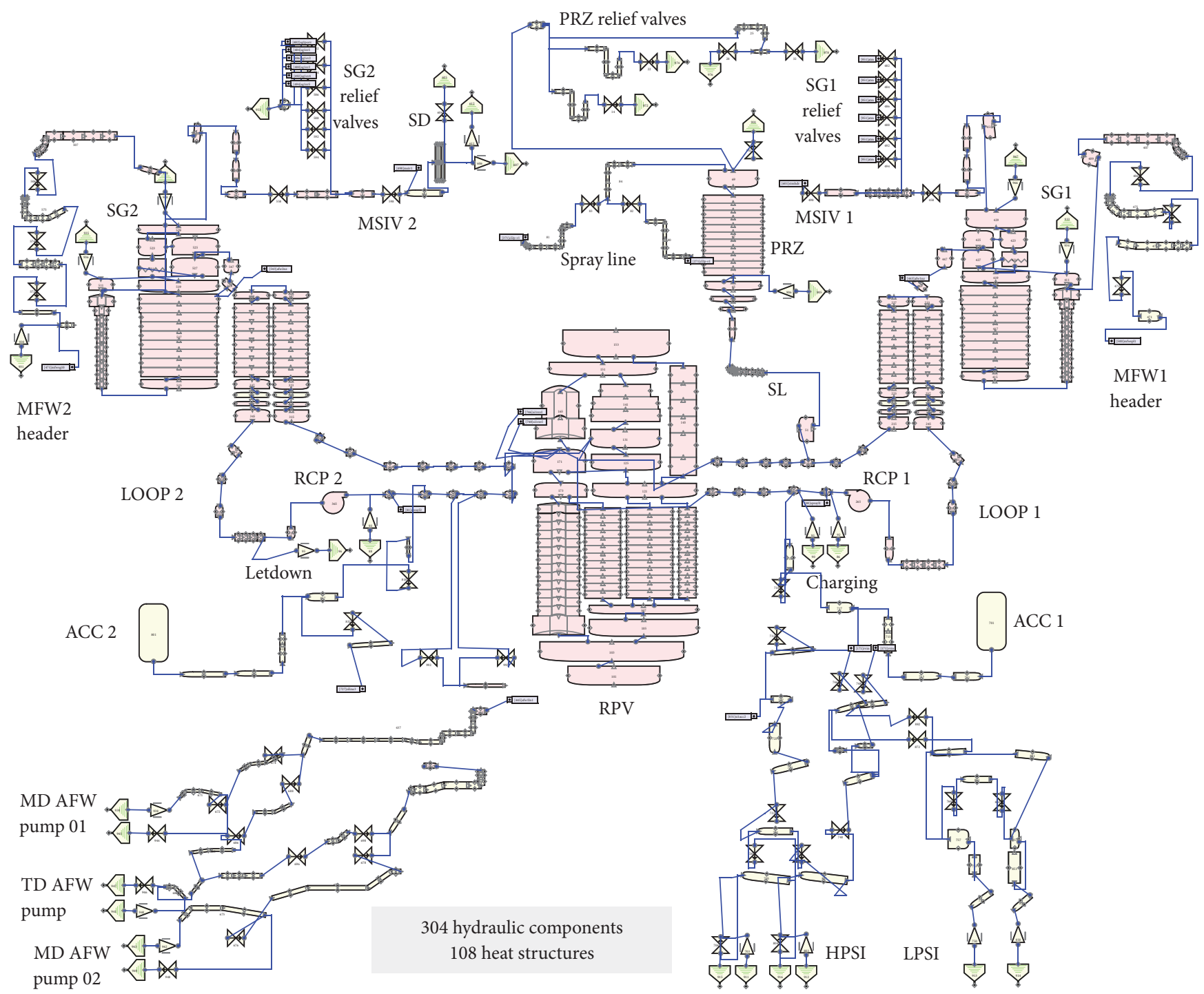

FIGURE 1: Krško NPP nodalization scheme: SNAP hydraulics component view.

The secondary side consists of the steam generators with main feedwater (MFW) and auxiliary feedwater (AFW) system. The secondary side is modelled (using the logic) up to turbine valve. The MFW and AFW pumps are modelled as time dependent junctions and turbine as time dependent volume.

The reactor protection system is modelled using trip logic. It includes reactor trip and safety injection signal. The safety injection signal actuates turbine trip signal, steam line isolation signal, MFW isolation signal, and AFW start signal.

Control variables and general tables are mainly used to model the control systems. Rod control system has been modelled for point kinetics. For maintaining the pressure and level in the primary system, pressurizer pressure and level control are modelled. Another control system modelled is steam dump system (see Figure 2), which is important for transient originated on the secondary side. The steam dump control system consists of turbine trip, loss of load, and steam pressure controllers. There are four groups of valves, labelled "a," "b," "c," and "d." In case of fast opening the bistables open groups "a," "b," "c," and "d" on HI-1 (high 1) demand ( $20 \%$ capacity), on HI- 2 demand (30\% capacity), on HI-3 demand (20\% capacity), and on HI- 4 demand ( $30 \%$ capacity), respectively.

\subsection{Initial and Boundary Conditions Used in RELAP5 Input} Model. The initial conditions used in the standard RELAP5 input model were compared to plant measured data (see Table 2). Because of good agreement between the plant measured data and RELAP5 values of initial conditions, there was no need to perform additional steady-state calculation.

The boundary conditions used for simulation are shown in Figure 3. For modelling the loss of external load, the artificial turbine control was used and the turbine power was given as boundary condition. Namely, the turbine power is 
TABLE 2: Initial conditions.

\begin{tabular}{lcc}
\hline Variable & Plant measured & RELAP5 \\
\hline Reactor power $(\%)$ & 100.3 & 100 \\
RCS average temperature $(\mathrm{K})$ & 577.96 & 578.15 \\
Hot leg temperature number 1/2 (K) & $596.79 / 596.79$ \\
Cold leg temperature number 1/2 (K) & $559.596 .51 / 559.32$ \\
Pressurizer pressure $(\mathrm{MPa})$ & $559.22 / 559.19$ & 15.513 \\
Steam generator pressure number 1/2 (MPa) & 15.509 & $6.438 / 6.415$ \\
Feedwater flow number 1/2 (kg/s) & $6.327 / 6.321$ & $541.34 / 544.47$ \\
Steam flow number $1 / 2(\mathrm{~kg} / \mathrm{s})$ & $550.4 / 549.6$ & $541.3 / 544.5$ \\
Feedwater temperature $(\mathrm{K})$ & $551.8 / 549.3$ & 565.55 \\
Steam generator narrow range level $(\%)$ & $\mathrm{N} . \mathrm{A}$. & $69.3 / 69.3$ \\
RCS boron concentration & $69.29 / 69.22$ & $1704 \mathrm{ppm}$ \\
\hline
\end{tabular}

\begin{tabular}{lll}
\hline Time: & Steam dump control & Krško NPP, Slovenia
\end{tabular}

\begin{tabular}{l} 
Os \\
\hline $1000 \mathrm{~s}$ \\
\hline
\end{tabular}
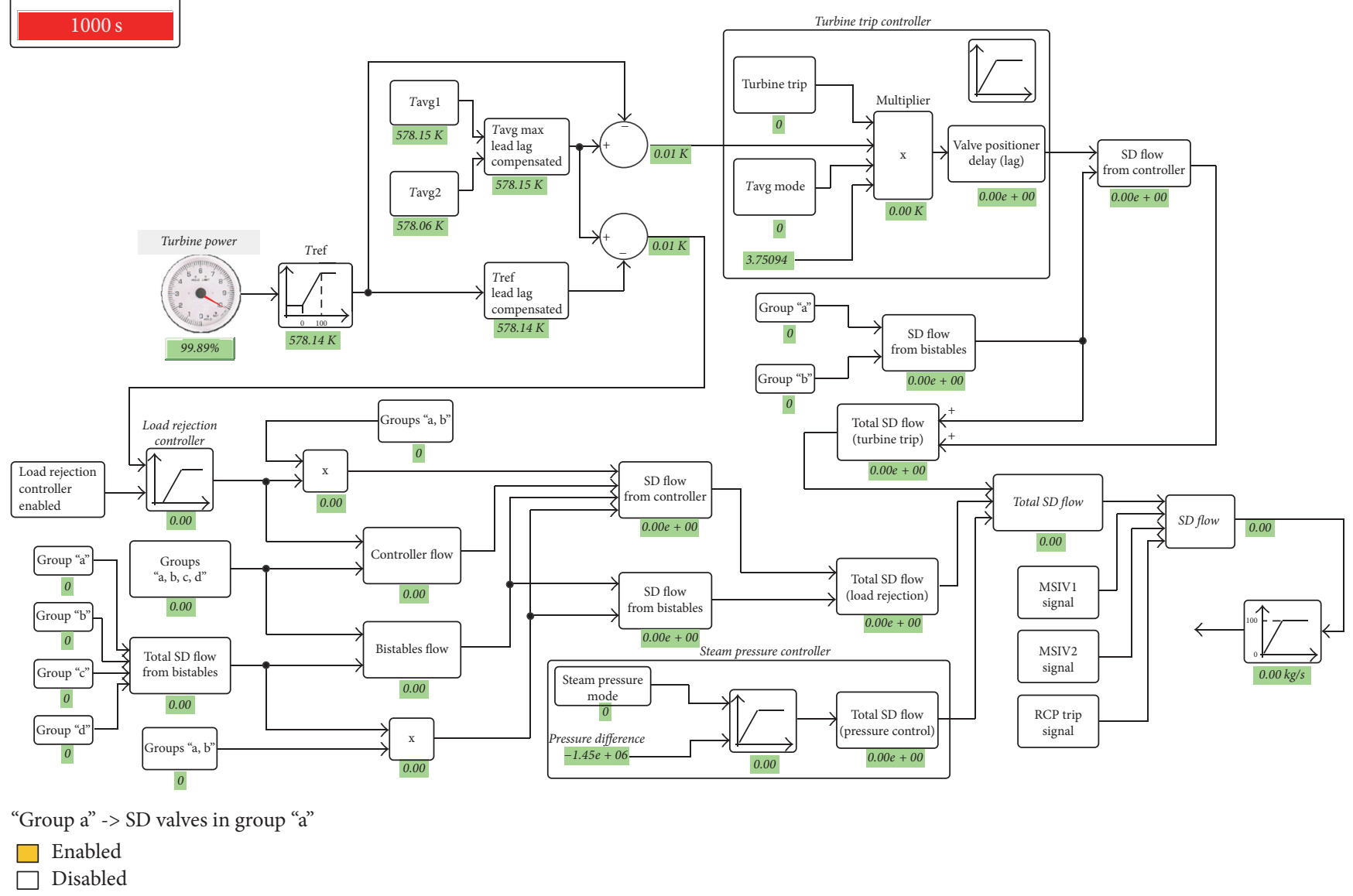

Turbine trip controller

FIGURE 2: RELAP5 animation mask of steam dump system.

a function of measured turbine first-stage pressure (i.e., impulse pressure), which is shown in Figure 3(a). The turbine external power represents the input into rod control and steam dump control system.

As there was no information on manual operation of main feedwater system, the measured feedwater flow shown in Figure 3(b) was used as boundary condition.
Because the secondary side is modelled up to the turbine and no turbine overspeed controller is modelled, the steam flow was input as boundary condition. The total steam flow was obtained by summing the measured steam flows in each steam line (see Figure 3(c)).

Finally, turbine-generator frequency in the plant influences the alternate current (AC) frequency. Again, due to 


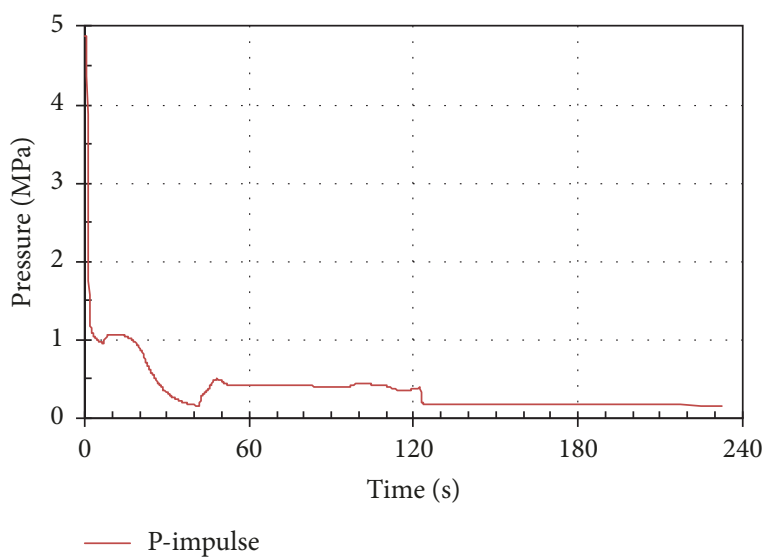

(a)

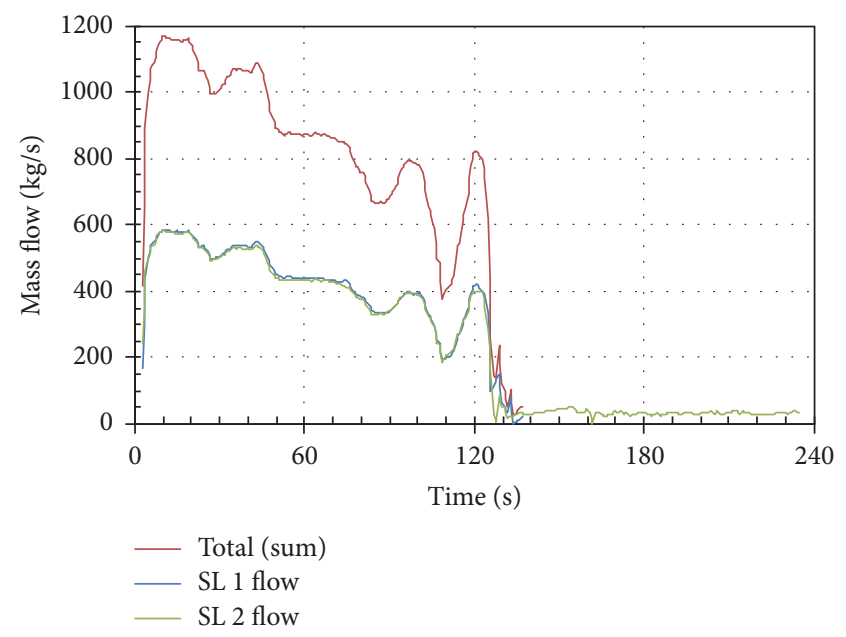

(c)

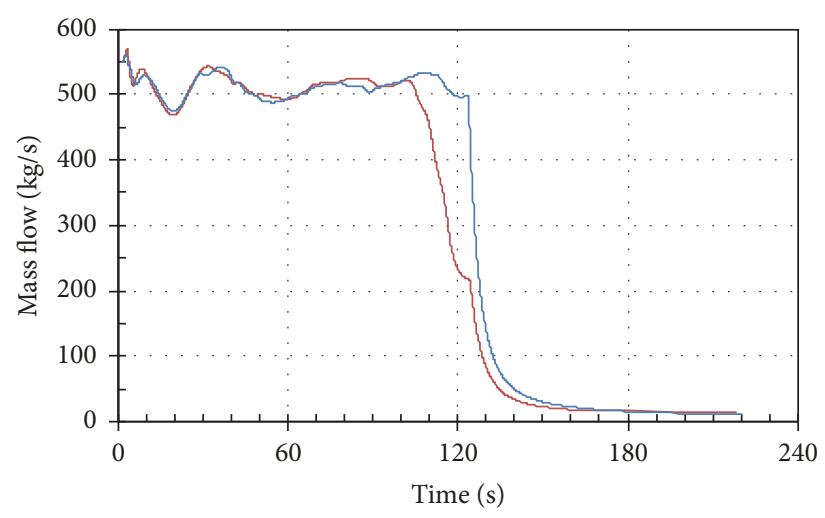

FW 1 flow

_ FW 2 flow

(b)

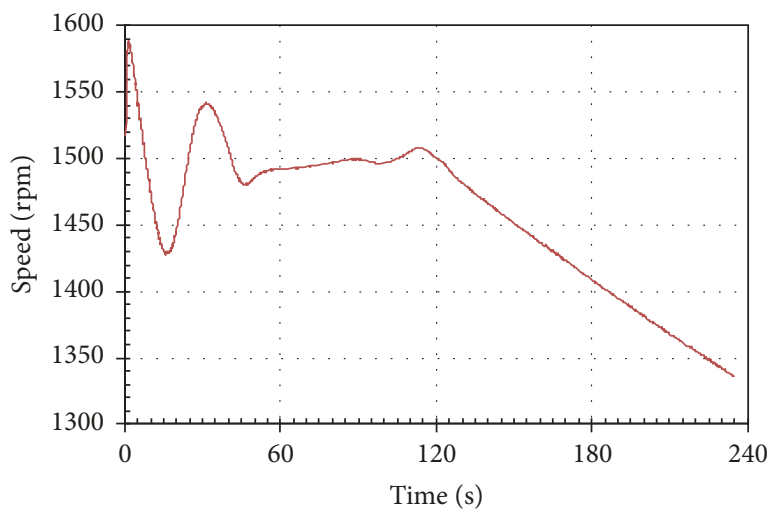

— TG rotor

Figure 3: Measured plant parameters: (a) turbine first-stage (impulse) pressure; (b) feedwater flow to steam generator numbers 1 and 2; (c) steam line number 1 and number 2 steam flow and total flow (summed steam line flows); (d) turbine-generator rotor speed.

missing turbine model, the influence of AC frequency (see Figure 3(d)) was inputted by reactor coolant pump rotor speed as boundary condition. Namely, reactor coolant pump flow depends on the rotor speed. It should be also noted that the main target of the automatic turbine control was to maintain the frequency at $50 \mathrm{~Hz}$ (speed $1500 \mathrm{rpm})$.

2.5. Description of Selected Scenarios. The analysis of abnormal event was performed in two steps. First we focused on the first part of transient till SI injection signal generation. Namely, only for scenarios in which SI signal was generated, it was meaningful to simulate the transient for the duration of measured data, that is, 4 minutes.

Table 3 shows scenarios selected for sensitivity analysis in the first step. Considered were also scenarios with operator action and plant responses not specified in the IRS 8300 report [11]. For example, the emergency boration was not reported in the IRS 8300 report [11]. We found the information on emergency boration in the internal plant report dealing with analysis of the event and scenario "w/o boration" was selected. Regarding the pressurizer PORV, the plant measured data show that pressurizer rate sensitive PORV did not open. The way to follow the plant response was therefore to disable pressurizer rate sensitive PORV opening. A case with not disabling pressurizer rate sensitive PORV has been also selected to see how plant input model behaves in such case (scenario "With PRZ PORV"). The turbine frequency change influences the $\mathrm{AC}$ frequency and the $\mathrm{AC}$ frequency influences the reactor coolant pump operation. The sensitivity run not considering $\mathrm{AC}$ frequency influence has been also performed (scenario "w/o frequency"). Further, in the base case simulation the boration was considered for the reactor power tuning. A sensitivity run without considering boration has been performed (scenario "w/o boration"), because no information on the emergency boration start and flowrate of boron injection was available. The scenario with main feedwater system in automatic mode of operation was performed (scenario "w/o operator FW") to verify the hypothesis that operator manual main feedwater control did not help in the secondary pressure stabilization. 
TABLE 3: Scenarios simulated by RELAP5 in the first step (till SI injection signal actuation).

\begin{tabular}{lc}
\hline Scenario & Name \\
\hline Base case (assuming above initial and boundary conditions) & Base \\
Base case without assuming influence of turbine-generator frequency on RCP flow & w/o frequency \\
Base case without disabled rate sensitive pressurizer PORV opening & With PRZ PORV \\
Base case without assuming any boration & w/o boration \\
Base case (assuming main feedwater system in automatic mode) & w/o operator FW \\
\hline
\end{tabular}

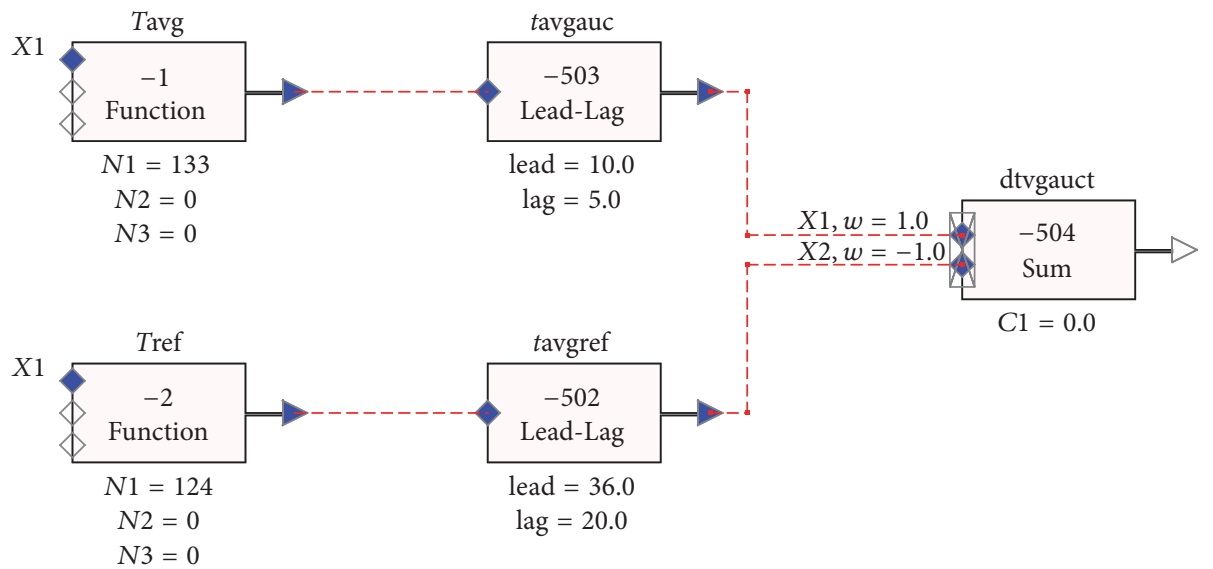

FIGURE 4: TRACE model of the input part of steam dump load rejection controller.

In the second step (simulating 4 minutes of transient) the base case scenario from Table 3 has been selected. Based on the analysis of measured data, additional scenario with assuming some steam release after SI signal generation has been performed. Namely, it is not logical that after steam line isolation on SI signal the measured steam flow at the exit of steam generators is nonzero (the validity sign for measured values was true), if there is no steam flow. Therefore, it may be assumed that the steam was released either through the SG PORVs or steam dump and scenario simulated was labelled "With SG PORV."

Because the steam dump flow and turbine flow were not measured, in the simulations the total steam flow was used as boundary condition. The purpose was to show that if the reactor and turbine power are balanced, the RELAP5 plant model is good representative of the plant response. Turbine power is represented by steam flow to the turbine. To get this flow, a total steam dump flow was first determined from measured highest RCS temperature (auctioneered) and the reference temperature (Tref) signals (see Figure 6(a)), which have been sent through steam dump load rejection controller. Because RELAP5 computer code is limited by the number of data points for input signals, the TRACE computer code has been used to model steam dump load rejection controller (see Figure 4). The output from the steam dump controller was the temperature error of the lead-lag compensated input signals, which determine the valve opening (see Figure 2), and the valve opening determines the steam dump flow. The difference between the total steam flow and total steam dump flow is the turbine flow, which has been used as boundary condition in scenario labelled "With TB flow."

The TRACE model for low steam line pressure signal compensation, shown in Figure 5, has been used to calculate the lead-lag compensated signal for low steam line pressure signals. Each steam line has three channels per steam line. To generate the SI signal, 2 out of 3 lead-lag compensated low steam line pressures are needed. Knowing the values of compensated steam line pressure signal helps in understanding the transient.

\section{Results}

3.1. Information Obtained from Analysis of Plant Measured Data. The input temperature signals into steam dump controller and their lead-lag compensated values are shown in Figure 6(a). The lead-lag compensated temperature error signal, which is used for load rejection input signal, is shown in Figure 6(b). The information available to operators is the temperature difference signal between RCS average and reference temperature. One may see that, after first 40 seconds, the lead-lag compensated temperature error signal and temperature difference signal agree well. The information on the turbine governor valve position indication is shown in Figure 6(c). One may see that after the transient start all four governor valves were closed to prevent overspeed of turbine-generator. Once the speed of turbine-generator started to drop (see Figure 3(c)), the first two governor valves partially reopen, but after full steam dump demand (see 

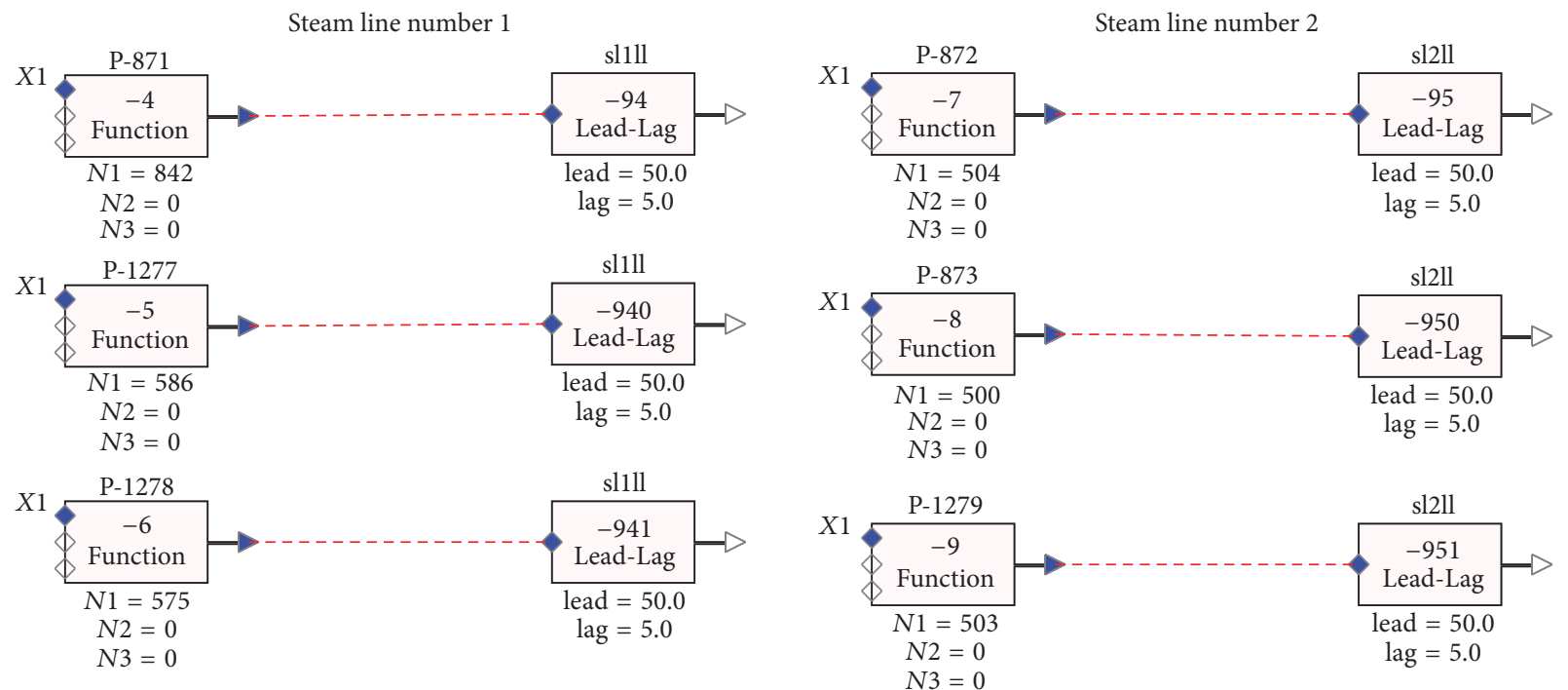

FIGURE 5: TRACE model for low steam line pressure signal compensation.

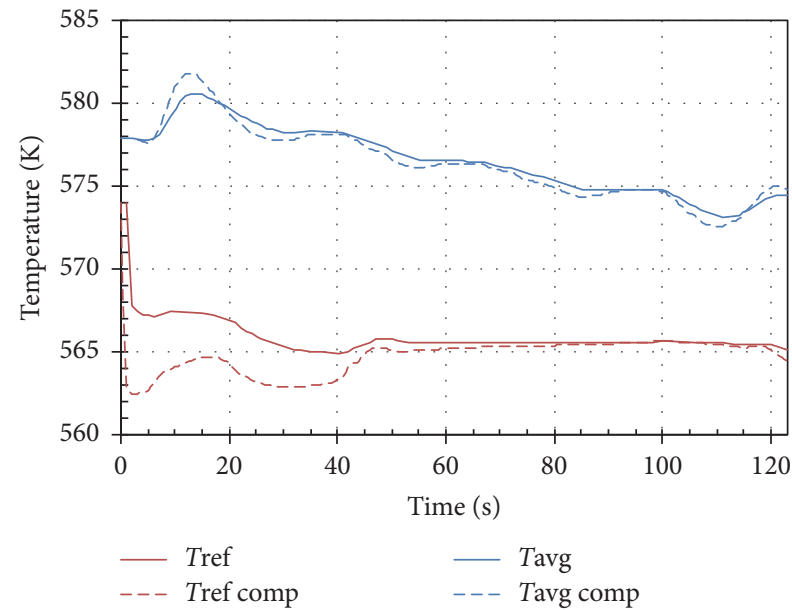

(a)

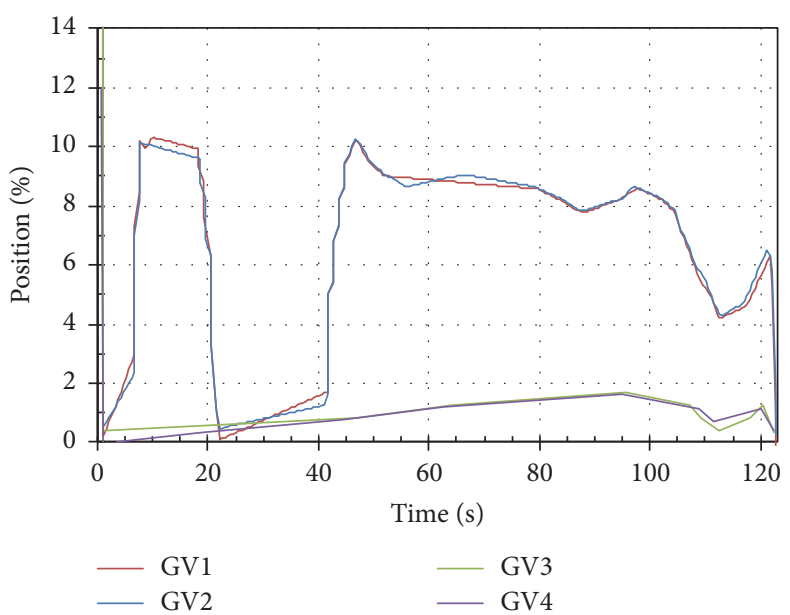

(c)

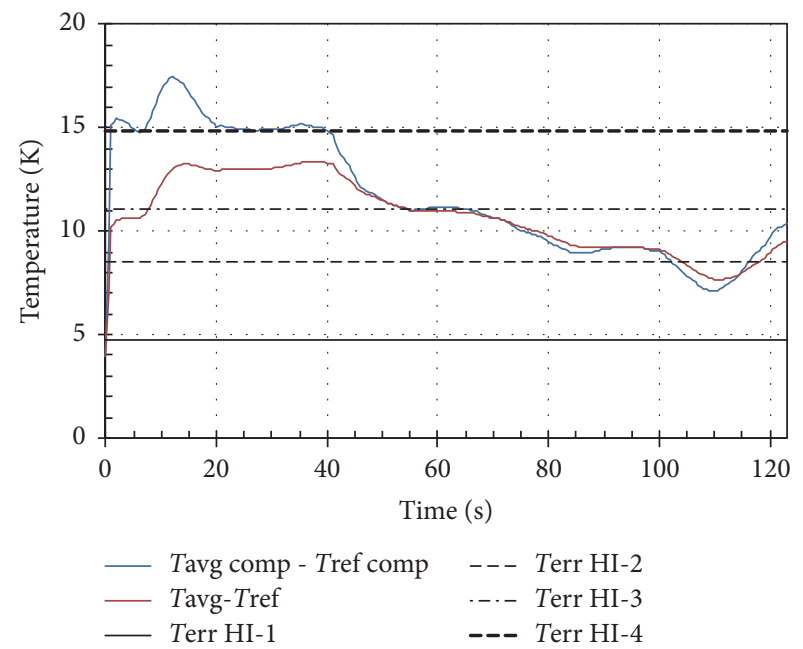

(b)

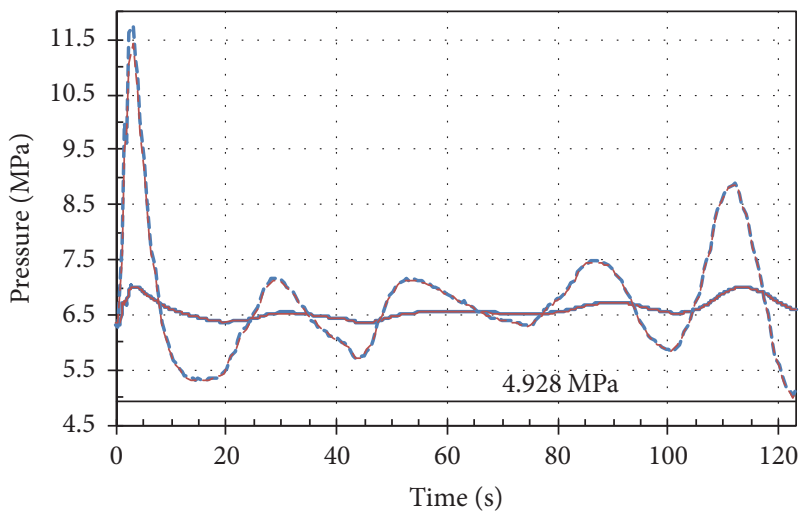

- SG number 1 - ch. $1 \quad$--- SG number 1 comp - ch. 1

--- SG number 2 comp - ch. 1

(d)

FIGURE 6: (a) Measured RCS average and reference temperature signal and the corresponding compensated signals; (b) measured error temperature signal for steam dump demand and the corresponding difference signal between RCS average and reference temperature; (c) turbine governor valve position indications; (d) steam generators pressures and compensated low steam line pressures. 
TABLE 4: TRACE calculated minimum values of low pressure compensated signals for both steam lines at around $10 \mathrm{~s}$.

\begin{tabular}{lccr}
\hline \multicolumn{2}{c}{ Steam line number 1 } & & \multicolumn{2}{c}{ Steam line number 2 } \\
Channel number & Value (MPa) & Channel number & 1 \\
1 & 5.119 & 2 & 5.051 \\
2 & 5.070 & 3 & 5.034 \\
3 & 5.118 & $(\mathrm{MPa})$ & 5.052 \\
\hline
\end{tabular}

Figure 6(b)) they started to close again after 17 seconds. When steam dump group " $d$ " valves fully close around $40 \mathrm{~s}$, the first two governor valves open again. Then the position of governor valves is rather constant until $90 \mathrm{~s}$. Five seconds later both the first two governor valves and steam dump group " $c$ " started to close, and another five seconds later also steam dump group "b" valves started to close. Due to overheating, the secondary side pressure increases. Turbine control reacted by reopening the valves. The steam dump demand reopens group " $b$ " valves. The secondary pressure dropped and due to the lead-lag compensated pressure signal the SI signal was actuated as shown in Figure 6(d). One may see that secondary pressure trend is far from dropping below low pressure setpoint of $4.928 \mathrm{MPa}$ which would be indication of steam line break.

Table 4 shows the minimum values of low pressure steam line pressure compensated signals predicted by TRACE model of steam dump control system at around $10 \mathrm{~s}$. It may be seen that already at this time the plant was close to SI signal actuation (i.e., minimum value below $4.928 \mathrm{MPa}$ ) which was prevented due to the closure of all turbine governor valves. Later at $95 \mathrm{~s}$, as already mentioned, the first two governor valves started to close again, and soon after $95 \mathrm{~s}$ also the steam dump group " $b$ " valves started to close. This is in agreement with steam flow shown in Figure 3(c). Closure of the valves resulted in the secondary pressure increase. Both turbine control and steam dump system therefore open the valves, but this time the lead-lag compensated steam line pressure dropped below setpoint and SI signal was actuated.

The lead constant has significant influence on compensated low steam line pressure (i.e., rate of pressure increase and drop). Therefore, the lead constant was parametrically varied and results are shown in Figure 7. Using lead constant $65 \mathrm{~s}$ in steam dump controller would cause SI signal actuation at around $10 \mathrm{~s}$. On the other hand, smaller lead constant would prevent SI signal actuation in the first two minutes.

3.2. Simulated Results till Plant SI Signal Actuation. The results are shown in Figures 8-10. The scenarios listed in Table 3 are compared. Base case calculation (labelled "Base") is performed considering both borations, changing $\mathrm{AC}$ frequency and disabling rate sensitive PRZ PORV number 2. Figure 8 (a) shows that when not considering boration (labelled "w/o boration") the core power significantly deviates

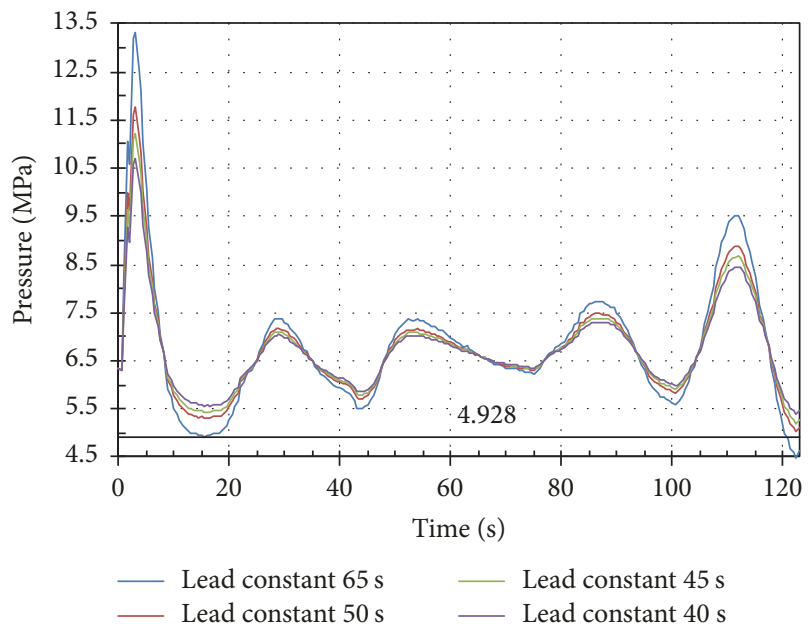

FIGURE 7: Calculated compensated low steam line pressures as a function of lead constant.

from the measured data. Therefore also all other important parameters deviate, as shown in Figures 8-10. The pressurizer pressure is higher (see Figure 8(b)), steam generator pressures are higher (see Figures 10(a) and 10(b)), and therefore low steam line pressure signals (see Figures 10(e) and 10(f)) are higher, not resulting in actuating the SI signal. The AC frequency change influencing the RCS flow increases the power (see Figure 8(a)) in first few seconds (not in the case "w/o frequency"). The power increase caused pressurizer pressure and steam generator pressures increase. According to the report [11] the PRZ PORV no. 1 and 2 did not open in first few seconds and this is in agreement with measured pressurizer pressure signal shown in Figure $8(\mathrm{~b})$. The consideration of rate sensitive PRZ PORV in the calculation mainly influences the pressurizer pressure in the initial period of 13 , but it is important for deeper understanding of the transient. The PRZ PORV no. 1 did not open in the simulation, while PRZ PORV no. 2 opened in simulation (case "With PRZ PORV") and by this prevented the significant pressure increase in the initial period (like in "w/o frequency case"). Figure 9 shows the hot leg, cold leg and average temperatures. They are in agreement with measured data. The exception is "w/o boration" and partly "w/o operator FW" case. For the latter case this is expected because of different control than in the case of manual operator control. Figure 10 shows the secondary side plant parameters. They are also in good agreement for all 


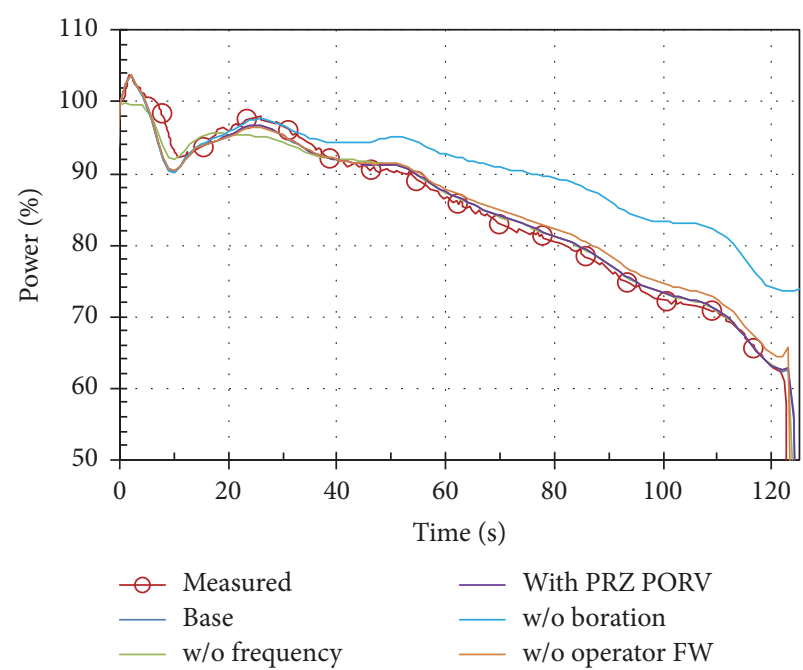

(a)

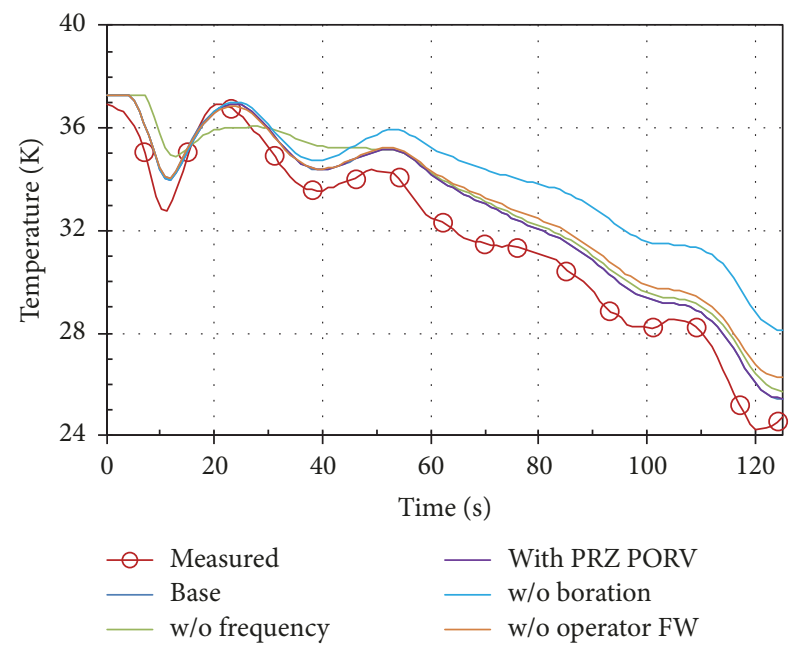

(c)

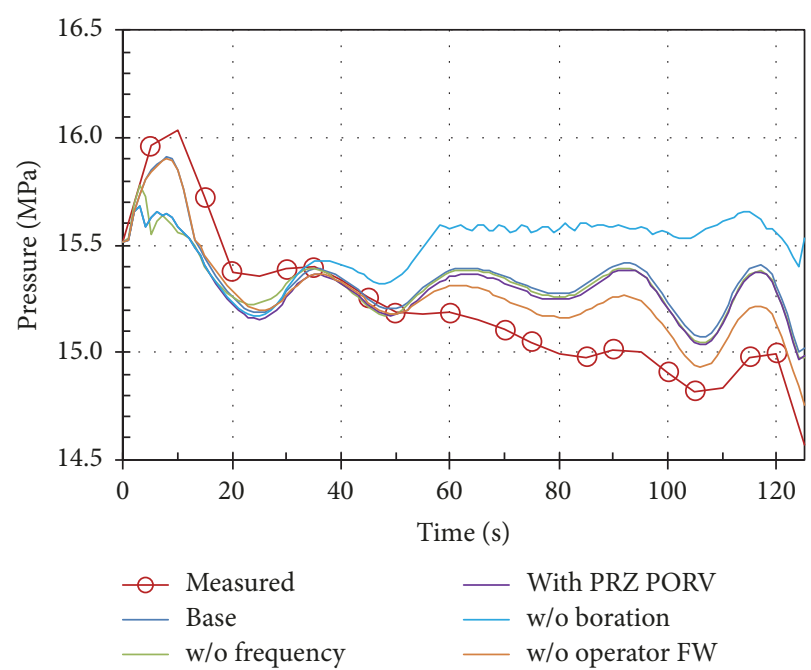

(b)

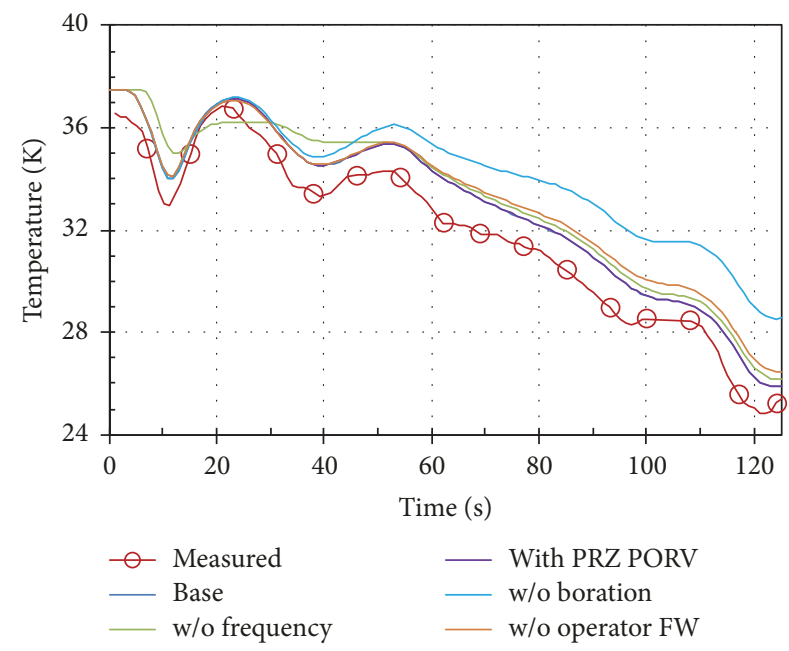

(d)

FIGURE 8: First part: (a) reactor power; (b) pressurizer pressure; (c) delta temperature number 1; (d) delta temperature number 2.

cases except "w/o boration" and partly "w/o operator FW" case. Figures $10(\mathrm{e})$ and $10(\mathrm{f})$ show low steam line compensated pressure no. 1 and 2, respectively, how they dropped below the setpoint for SI signal actuation.

3.3. Simulated Results till the Measurement End Time. The results for duration till the measurement end time are shown in Figures 11 and 12. Two new scenarios have been studied. First was a scenario simulating some steam flow after SI signal actuation (labelled "With SG PORV"). The SI signal actuates the main steam line isolation, but measured steam slow at the exit of steam generators is nonzero (see Figure 3(c)). If main steam line isolation occurred, the steam may be discharged through the SG PORVs. If not, the steam may be discharged to steam dump. The influence of steam flow on the steam generator pressures is shown in Figures 11(c) and 11(d) and on the cold leg temperatures shown in Figures 12(a) and 12(b).
The simulation results using turbine flow instead of total steam flow as boundary condition and steam dump model ("With TB flow" case) are quite similar to "Base" simulation results. This finding suggests that turbine flow was correctly predicted.

3.4. Discussion of Results. The results suggest that available plant information on systems performance is crucial for the whole transient duration simulation. If not available, the calculated plant response may be different comparing to the measured data. Also it was demonstrated that some measured data may be used to reproduce some missing information. For example, the steam dump demand signal has been reproduced, which enables calculation of turbine flow. Another example is calculation of compensated low steam 


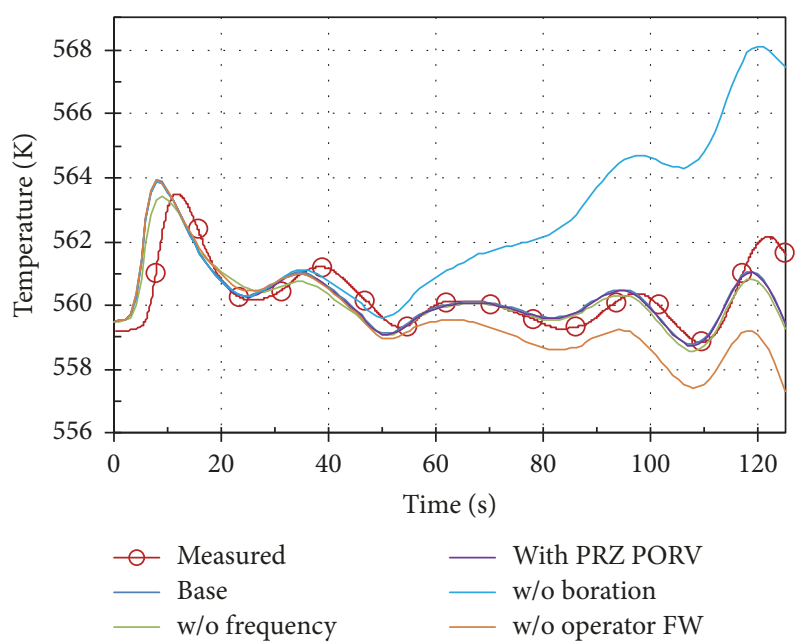

(a)

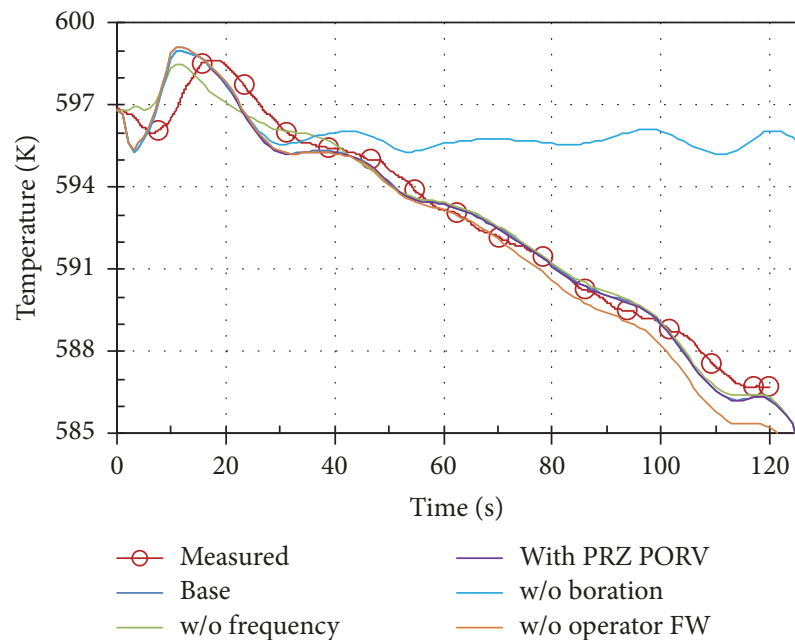

(c)

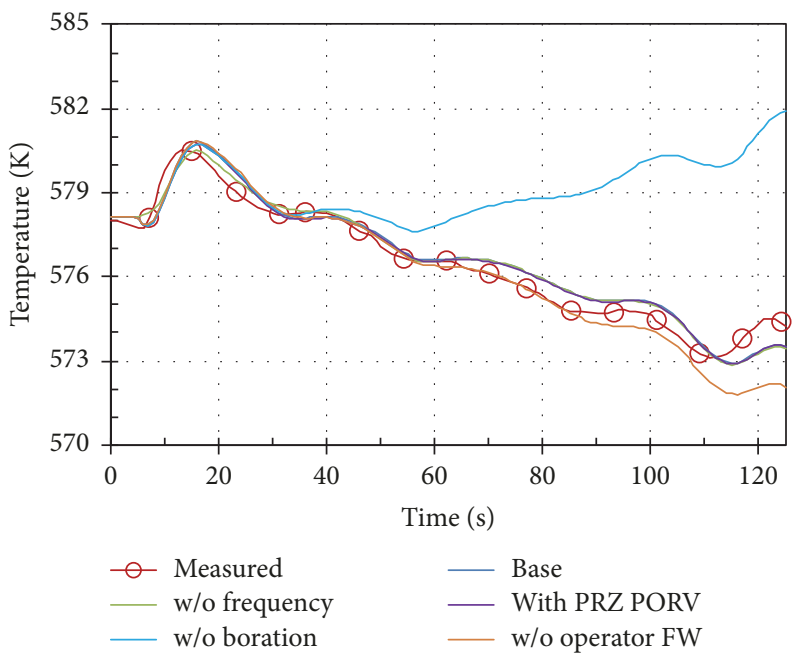

(e)
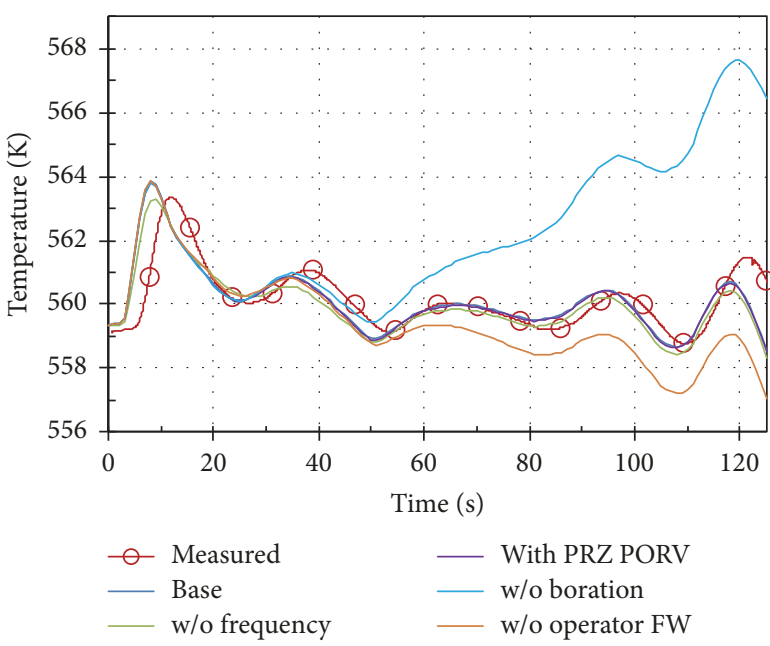

(b)
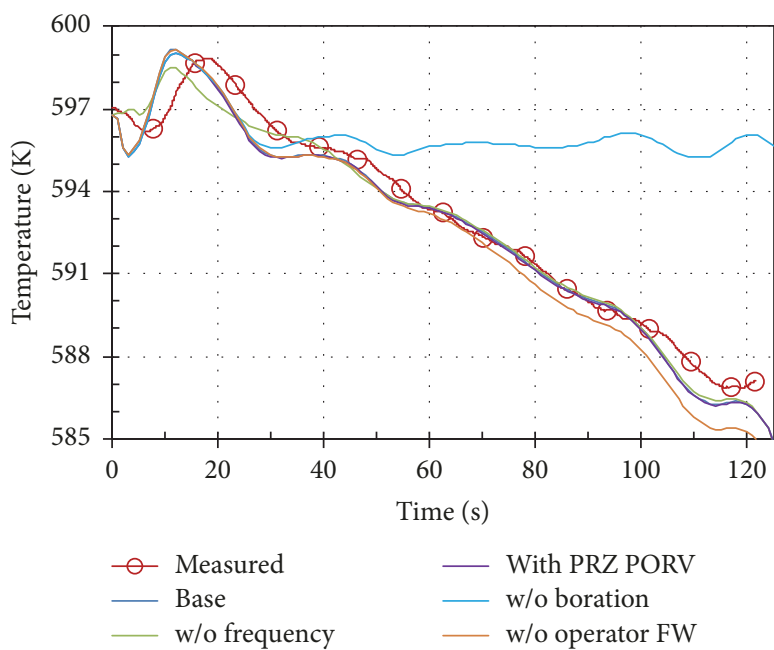

(d)

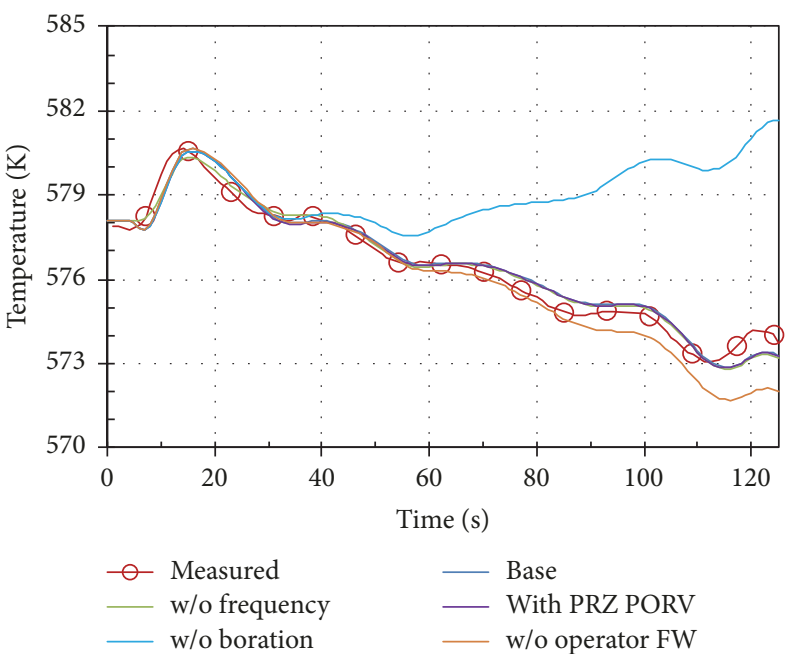

(f)

FiguRE 9: First part: (a) cold leg number 1 temperature; (b) cold leg number 2 temperature; (c) hot leg number 1 temperature; (d) hot leg number 2 temperature; (e) RCS loop number 1 average temperature; (f) RCS loop number 2 average temperature. 


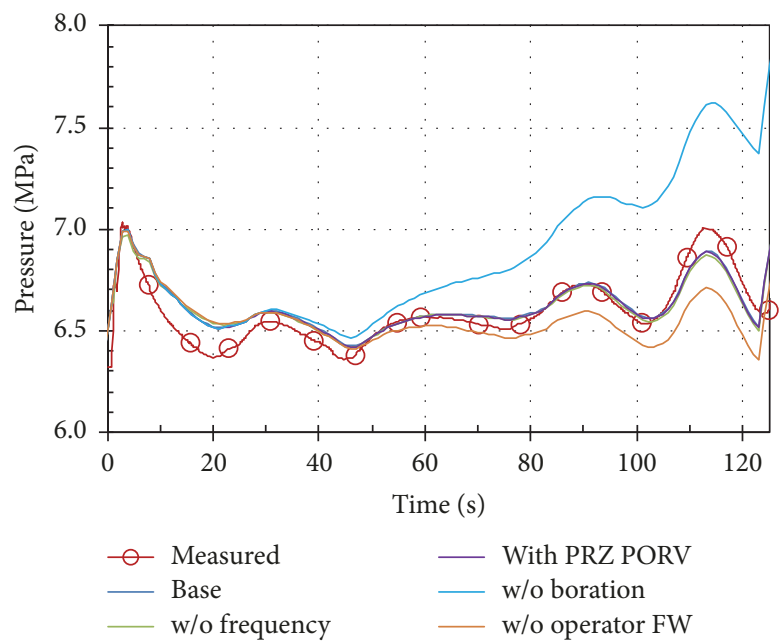

(a)
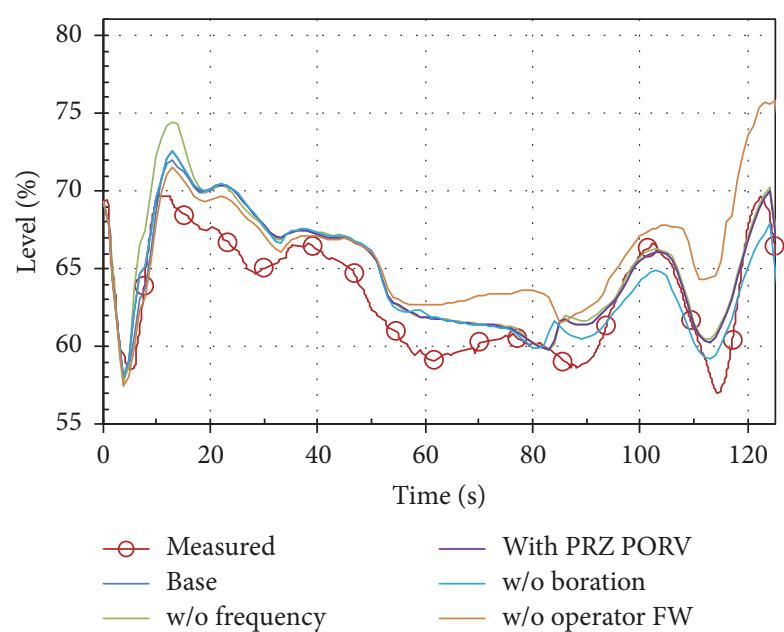

(c)
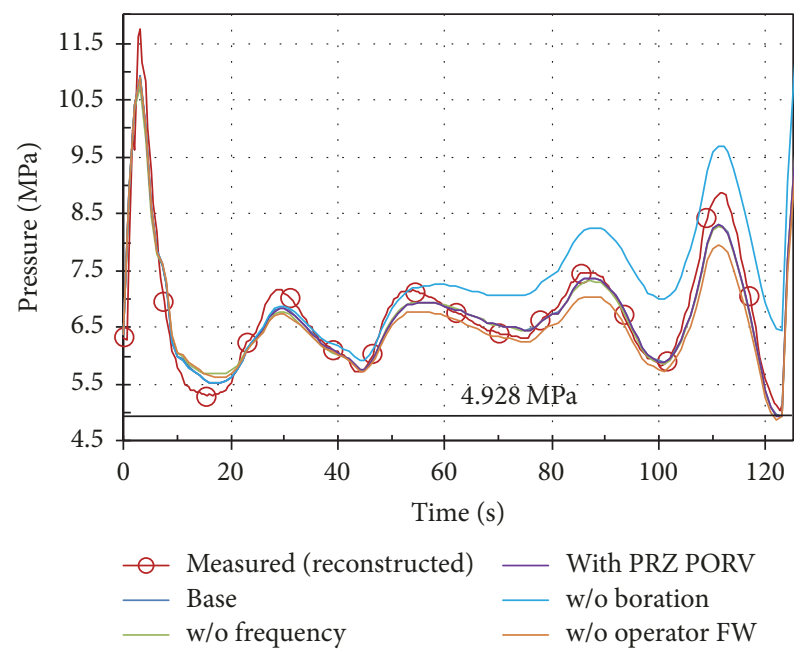

(e)
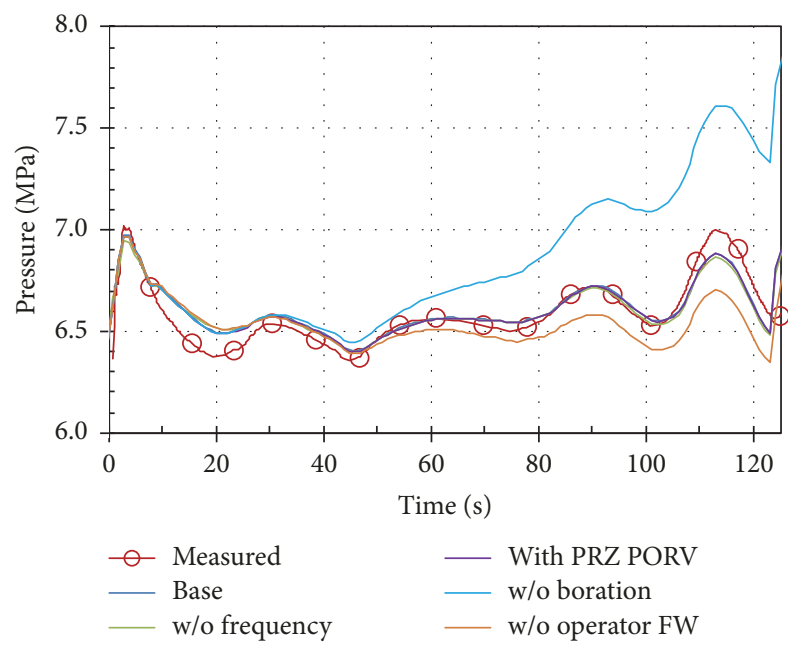

(b)

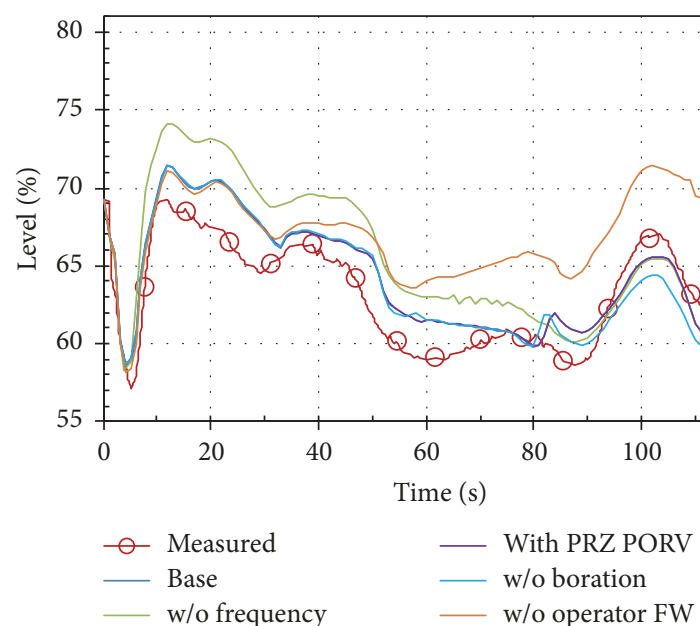

(d)

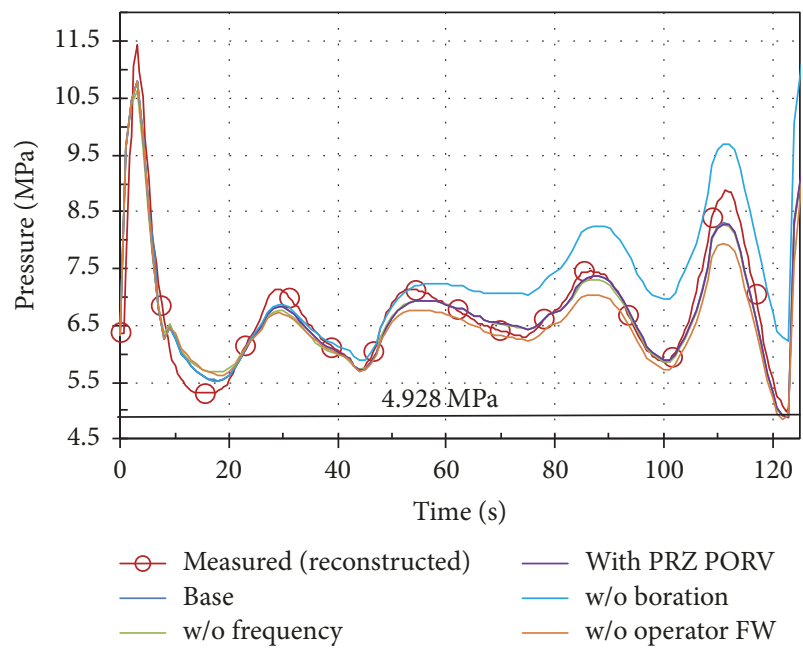

(f)

FIGURE 10: First part: (a) SG number 1 pressure; (b) SG number 2 pressure; (c) SG number 1 narrow range level; (d) SG number 2 narrow range level; (e) LO-2 steam line number 1 pressure signal; (f) LO-2 steam line number 2 pressure signal. 

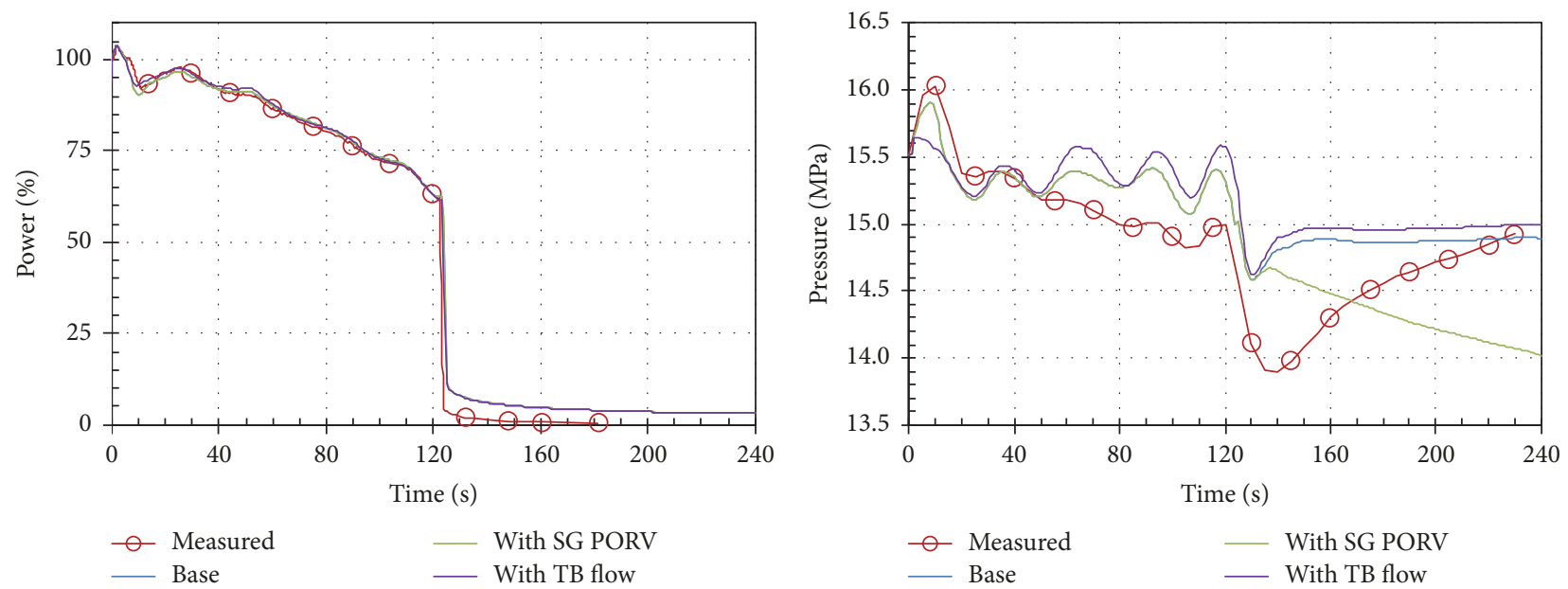

(a)
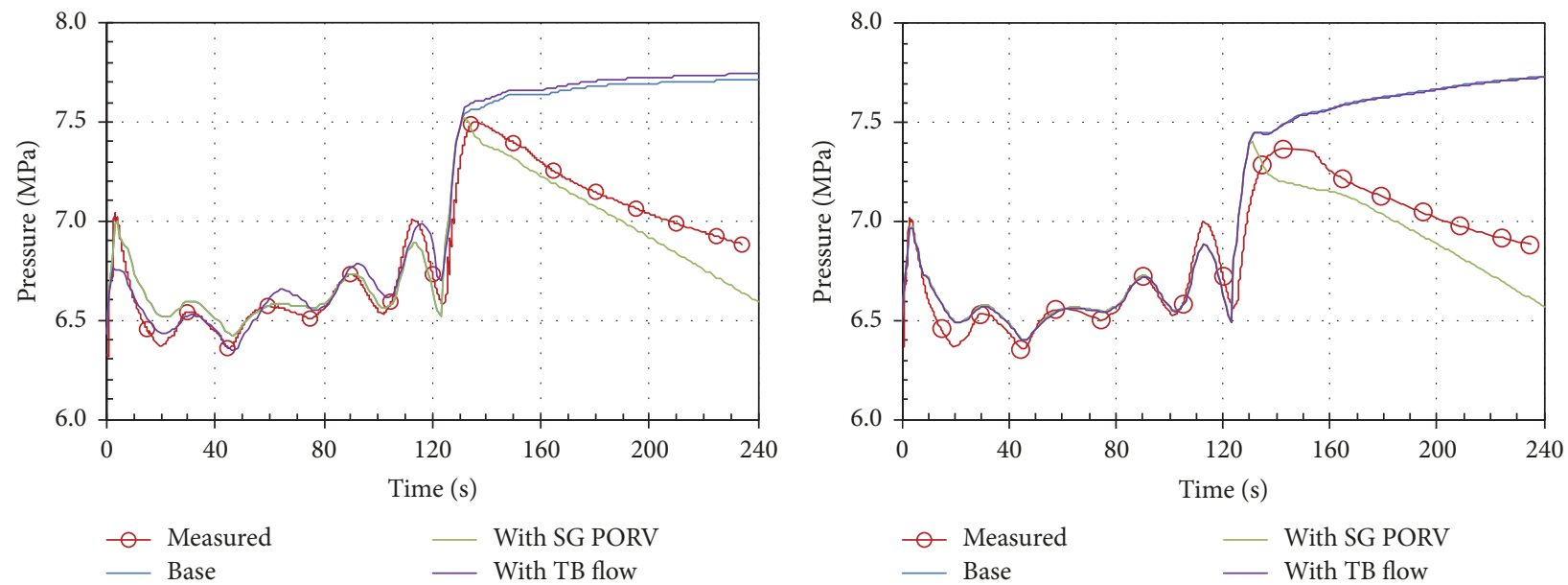

(c)
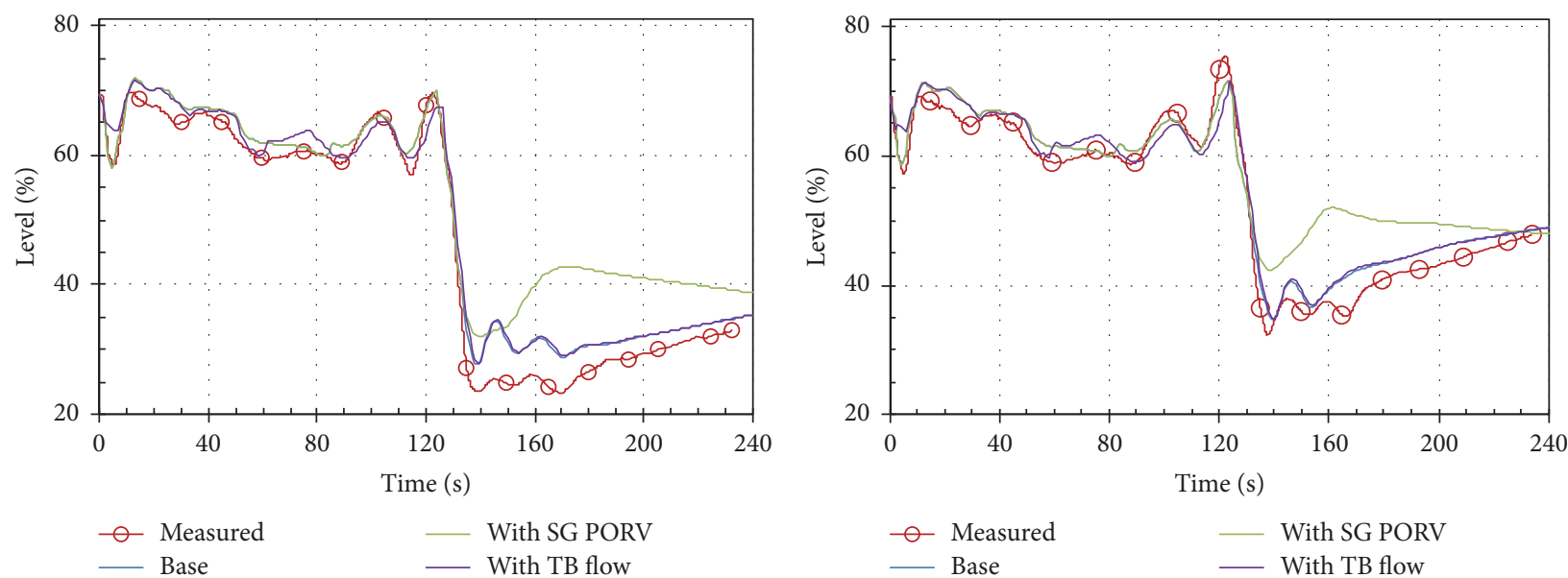

(e)

(f)

FIGURE 11: Second part: (a) reactor power; (b) pressurizer pressure; (c) SG number 1 pressure; (d) SG number 2 pressure; (e) SG number 1 narrow range level; (f) SG number 2 narrow range level. 


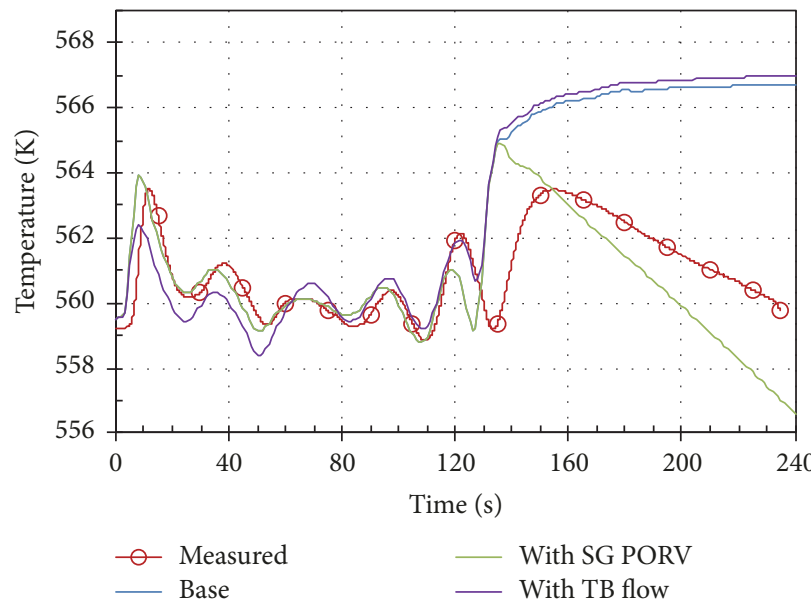

(a)

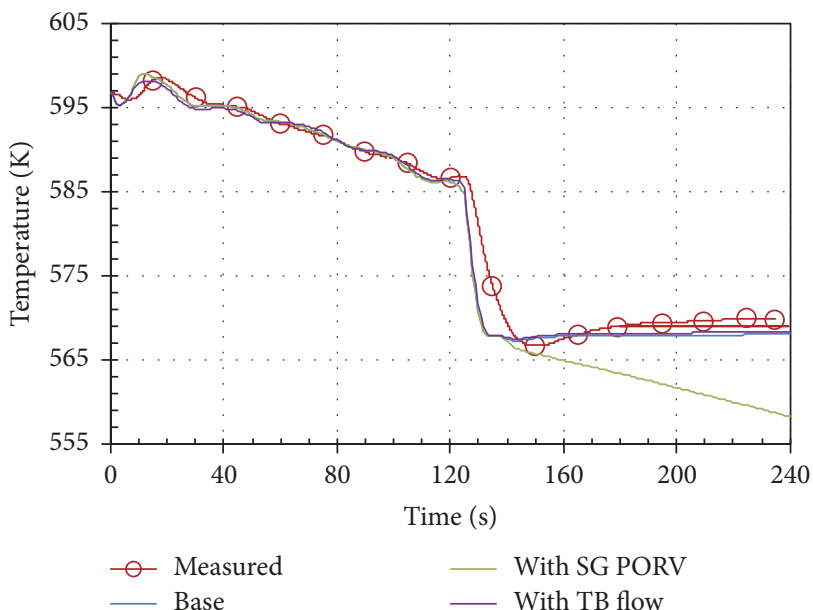

(c)

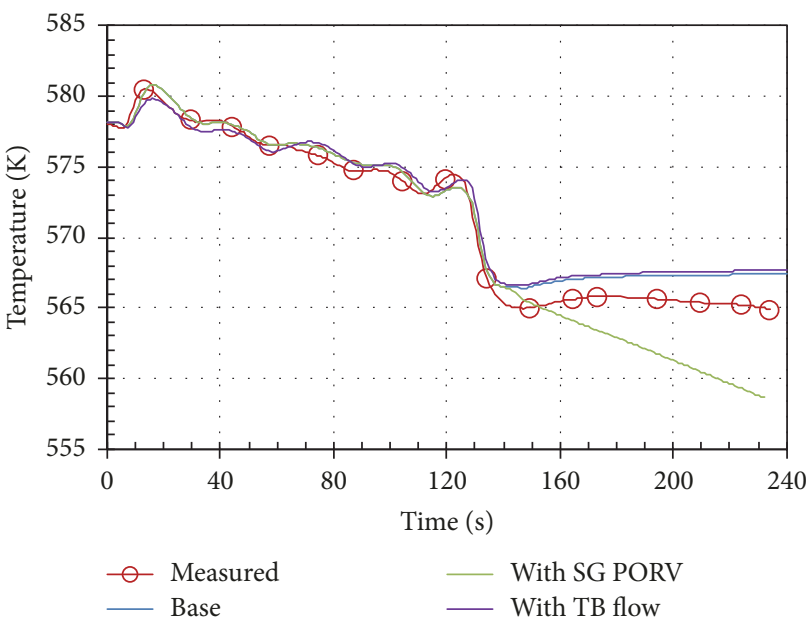

(e)

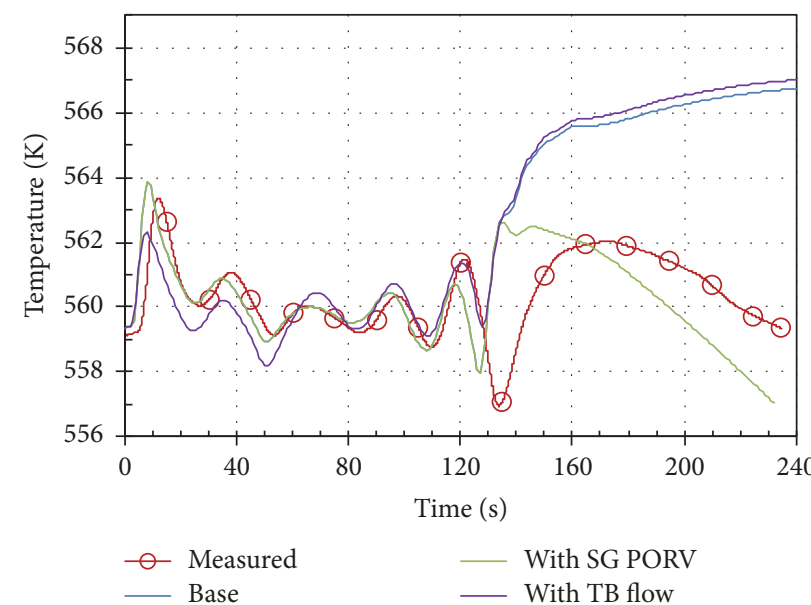

(b)

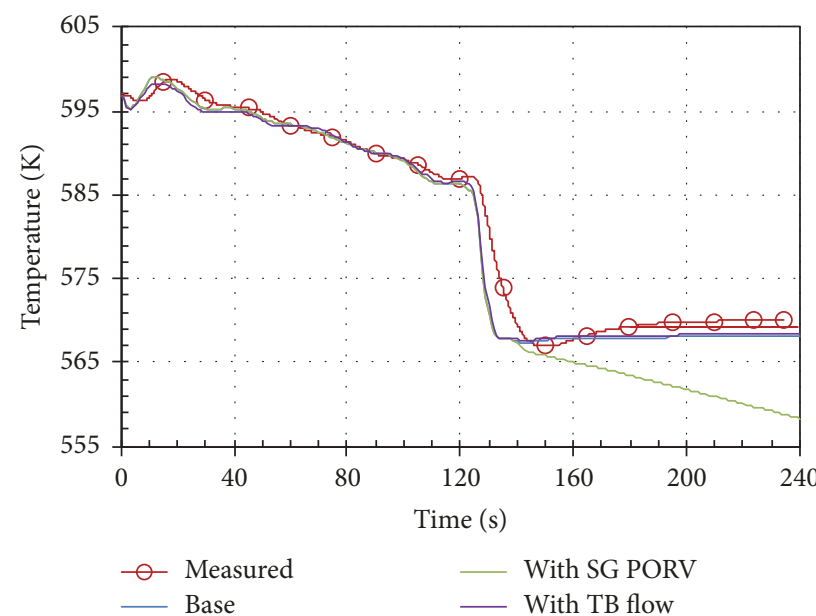

(d)

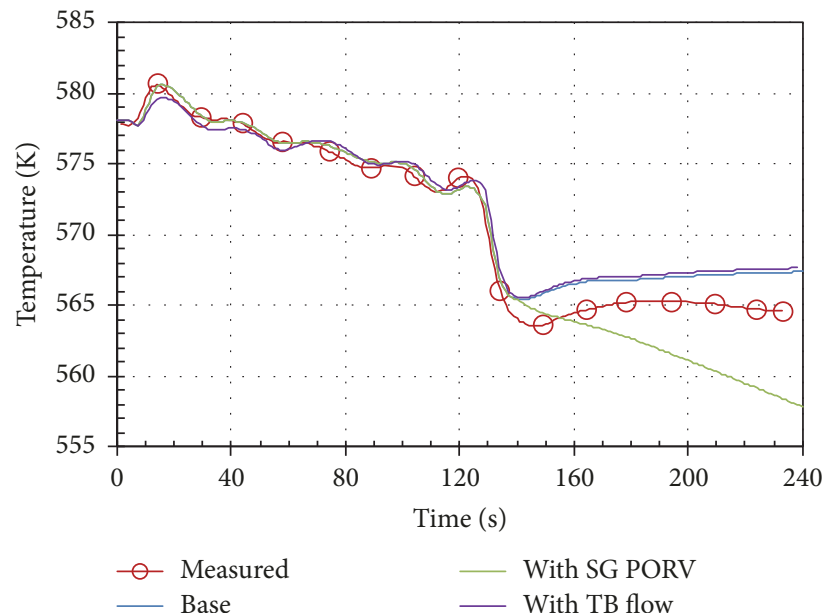

(f)

Figure 12: Second part: (a) cold leg number 1 temperature; (b) cold leg number 2 temperature; (c) hot leg number 1 temperature; (d) hot leg number 2 temperature; (e) RCS loop number 1 average temperature; (f) RCS loop number 2 average temperature. 
line pressure signals from steam line pressure signals. Namely, the safety injection signal is actuated on compensated signal. With such information the plant transient could be better understood, especially the operation of turbine valve control and steam dump system. Also, the hypothesis that operator manual main feedwater control did not help in secondary pressure stabilization has been confirmed by simulation. Finally, one important finding seems to be as follows: almost simultaneous request of two independent controllers (turbine control and steam dump load rejection controller, resp.) besides fast lead constant for pressure compensation may be the reason for SI signal actuation due to fast rate of compensated pressure change. Also, the main target of automatic turbine control was to control the speed of the turbinegenerator and not to stabilize the steam line pressure.

\section{Conclusions}

The abnormal event with loss of external load, followed by safety injection actuation and reactor trip has been simulated with the latest RELAP5/MOD3.3 Patch 05 best-estimate thermal hydraulic computer code. Comparison between calculated data and plant measured data suggests that RELAP5 code is appropriate for simulating such abnormal events. It was demonstrated that certain measured data may be used to reproduce some missing information. The steam dump demand signal has been reproduced from measured average and reference temperature signals, which enables calculation of turbine flow. This further explains operation of the automatic turbine control besides the steam dump system operation. The hypothesis that operator manual main feedwater control did not help in secondary pressure stabilization has been confirmed by simulation. It has been shown how the steam generator pressure change and lead constant influence the low steam pressure compensated signal designed to actuate the safety injection signal. It can be concluded that simulation tools like RELAP5/MOD3.3 can provide valuable insights into the plant response.

\section{Conflicts of Interest}

The authors declare that there are no conflicts of interest regarding the publication of this paper.

\section{Acknowledgments}

The authors acknowledge the financial support from the Slovenian Research Agency (Research Core Funding no. P20026 "Reactor Engineering”). The Krško Nuclear Power Plant (NPP Krško) and Slovenian Nuclear Safety Administration (SNSA) supported this research through CAMP Project no. POG-U3-KE-R4/104/12 (NEK no. 3120118).

\section{References}

[1] A. Prošek, B. Kvizda, B. Mavko, and T. Kliment, "Quantitative assessment of MCP trip transient in a VVER," Nuclear Engineering and Design, vol. 227, no. 1, pp. 85-96, 2004.
[2] A. Prošek and I. Parzer, "Quantitative assessment of MSIV closure events in Krško NPP calculated by RELAP5/MOD3.3," in Deterministic analysis of operational events in nuclear power plants: proceedings of a technical meeting held in Dubrovnik, Croatia, pp. 13-21, IAEA, Vienna, Austria, May 2005, (IAEATECDOC, 1550). IAEA. 2007.

[3] A. Prošek and B. Mavko, "RELAP5/MOD3.3 code validation with plant abnormal event," Science and Technology of Nuclear Installations, vol. 2008, Article ID 745178, 2008.

[4] J.-R. Wang, H.-T. Lin, Y.-H. Cheng, W.-C. Wang, and C. Shih, "TRACE modeling and its verification using Maanshan PWR start-up tests," Annals of Nuclear Energy, vol. 36, no. 4, pp. 527536, 2009.

[5] F. Reventós, C. Llopis, L. Batet, C. Pretel, and I. Sol, "Analysis of an actual reactor trip operating event due to a high variation of neutron flux occurring in the Vandells-II nuclear power plant," Nuclear Engineering and Design, vol. 240, no. 10, pp. 2999-3008, 2010.

[6] C. Queral, A. Expósito, G. Jiménez, L. Valle, and J. C. MartínezMurillo, "Assessment of TRACE 4.160 and 5.0 against RCP Trip Transient in Almaraz I Nuclear Power Plant," NUREG/IA-0233, US Nuclear Regulatory Commission, July 2010.

[7] J. Bánáti and M. Holmgren, "Validation of RELAP5/MOD3.3 against a load step transient at Ringhals 4 NPP," in Proceedings of the 16th International Conference on Nuclear Reactor Thermal Hydraulics (NURETH '16), Chicago, IL, USA, August 2015.

[8] International Atomic Energy Agency, "Deterministic safety analysis for nuclear power plants," in Specific Safety Guide (SSG2), IAEA, Vienna, Austria, 2009.

[9] A. Prošek and M. Matkovič, "RELAP5/MOD3.3 analysis of event with actuation of safety injection system at the loss of external power," International agreement report, NUREG/IA0458, U.S. Nuclear Regulatory Commission, Washington, USA, 2015.

[10] USNRC, RELAP5/MOD3.3 Code Manual, vol. 1-8, patch 05, Information Systems Laboratories, Inc., Rockville, MD, USA, 2016.

[11] International Incident Reporting System (IRS), Reactor Trip and Actuation of Safety Injection System Caused by the Spurious Activation of Bus Protection in $400 \mathrm{KV}$ Switchyard, International Incident Reporting System (IRS), 2012.

[12] A. Prošek, I. Parzer, and B. Krajnc, "Simulation of hypothetical small-break loss-of-coolant accident in modernized nuclear power plant," Electrotechnical Review, vol. 71, no. 4, pp. 191-196, 2004.

[13] I. Parzar, B. Mavko, and B. Krajnc, "Simulation of a hypothetical loss-of-feedwater accident in a modernized nuclear power plant," Journal of Mechanical Engineering, vol. 49, no. 9, pp. 430444, 2003. 

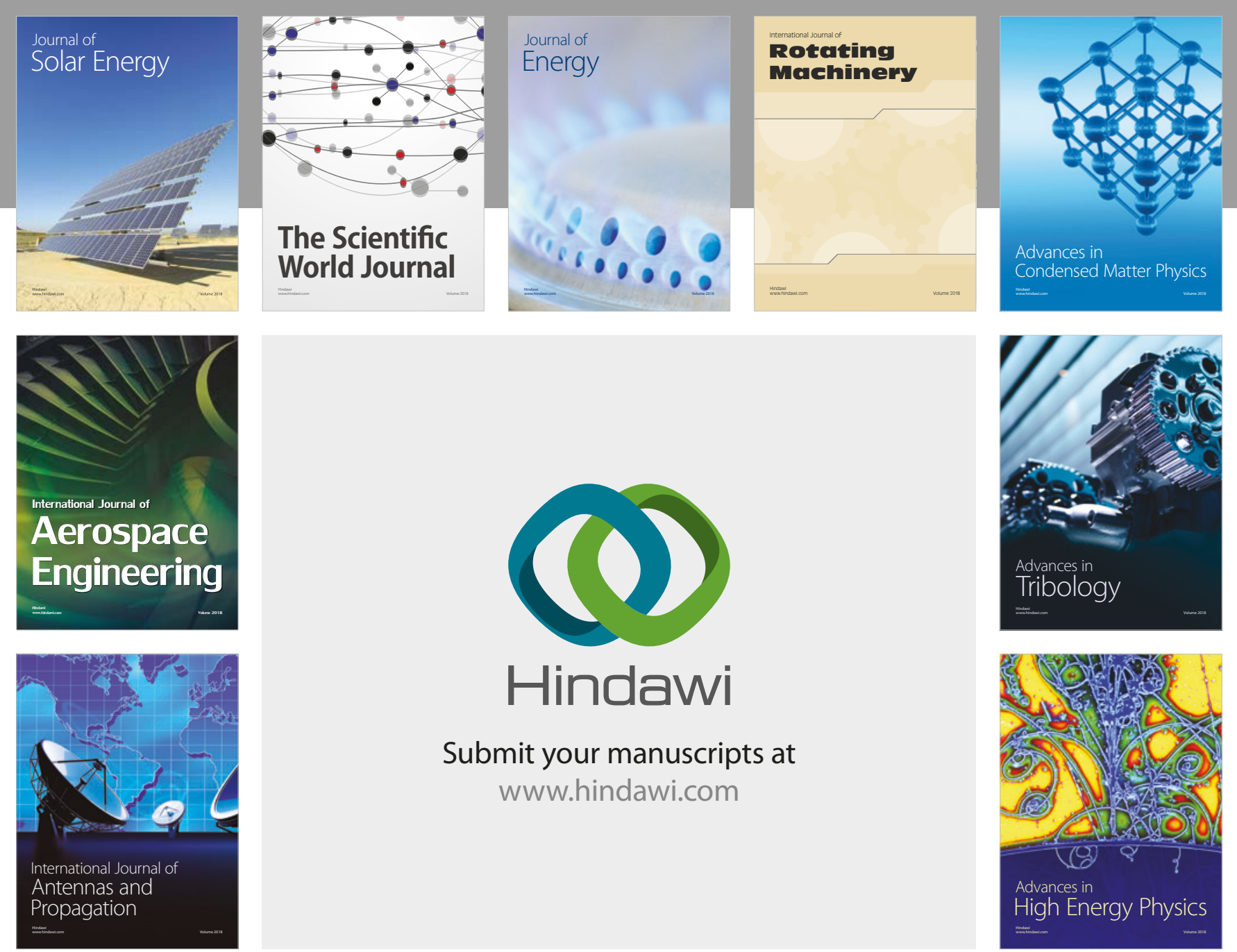

Submit your manuscripts at

www.hindawi.com
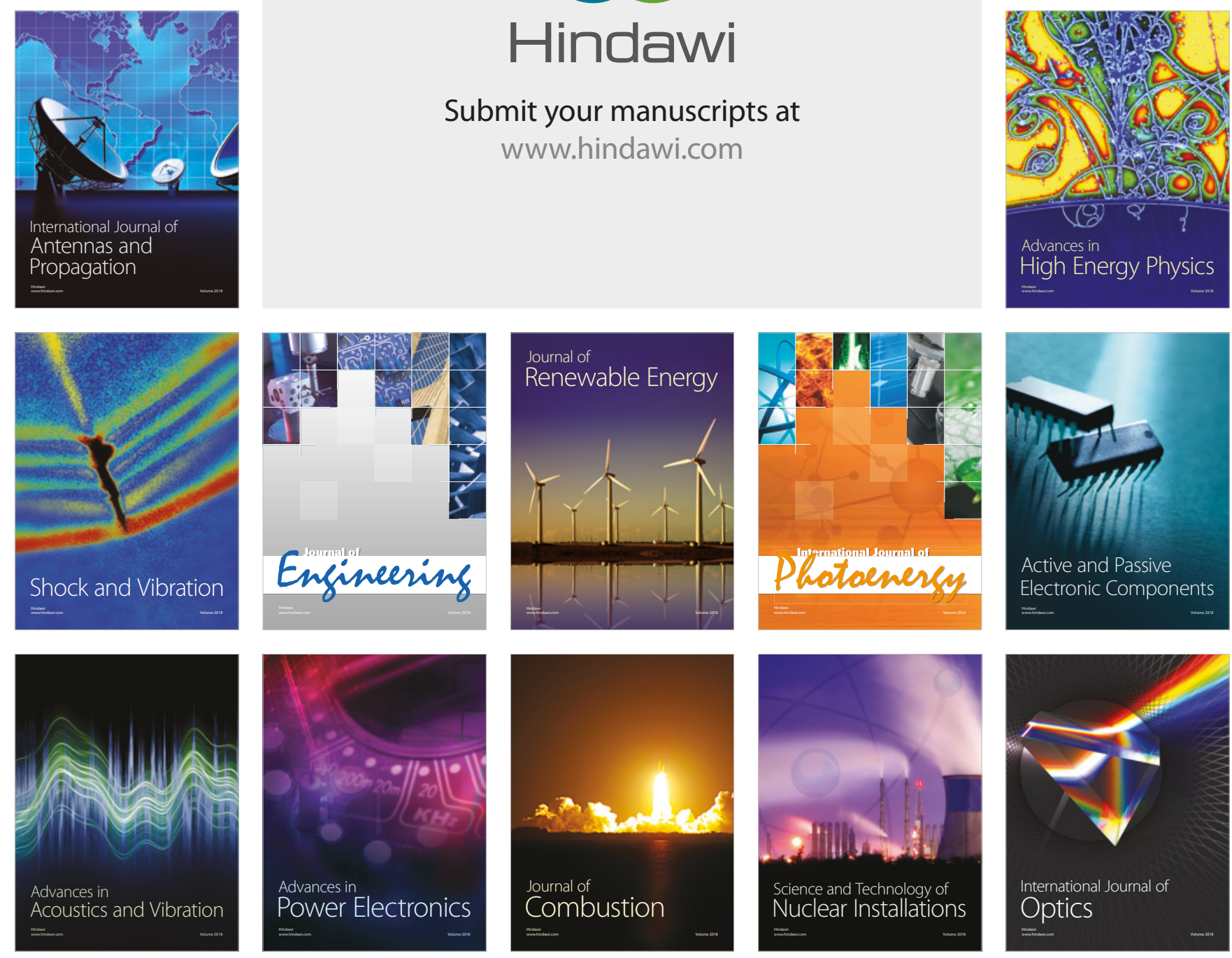